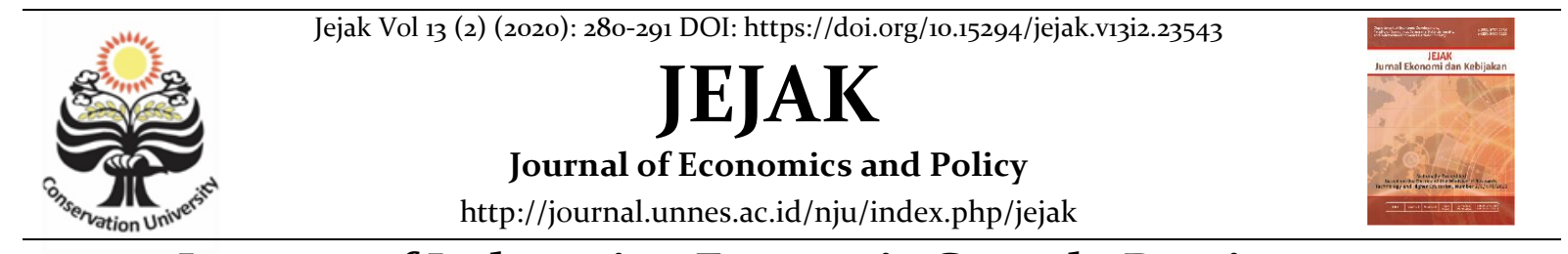

\title{
Impacts of Indonesian Economic Growth: Remittances Migrant Workers and FDI
}

\author{
Khairah Ukhtiyani ${ }^{\bowtie},{ }^{2}$ Setyabudi Indartono \\ ${ }^{1,2}$ Universitas Negeri Yogyakarta \\ Permalink/DOI: https://doi.org/10.15294/jejak.v13i2.23543 \\ Received: May 2020; Accepted: July 2020; Published: September 2020
}

\begin{abstract}
This study aims to identify: (1) the effect of remittance of Indonesian workers on Indonesia's economic growth from 1998-2018; (2) the effect of Foreign Direct Investment on Indonesia's economic growth from 1998-2018; and (3) the effect of remittances of Indonesian workers and Foreign Direct Investment (FDI) on Indonesia's economic growth from 1998-2018. Based on previous studies found differences in the results of contributions. This study uses a quantitative model using remittances from Indonesian workers and FDI as independent variables, and the dependent variable is economic growth. The population of this study is all secondary data about the percentage of GDP and FDI remittances and the level of economic growth in Indonesia in 1998-2018. Tests conducted are prerequisite tests for multicollinearity, heteroscedasticity, autocorrelation, and multiple regression hypothesis testing using SPSS 21 to measure the effect of independent variables on the dependent variable partially and simultaneously. The results of this study stated that there was no significant effect on the remittance of Indonesian workers and FDI on Indonesia's economic growth from 1998-2018 because the receipt of remittances by Indonesian workers was used by households for food consumption and expenditure, not for investment or to open businesses. Meanwhile, Indonesia's FDI bureaucracy is still inefficient and there is a need for infrastructure development to increase foreign investor interest. In addition, Indonesia is still oriented towards imports rather than exports.
\end{abstract}

Key words : Remittances Migrant Workers, FDI, Indonesian Economic Growth.

How to Cite: Ukhtiyani, K., \& Indartono, S. (2020). Impacts of Indonesian Economic Growth: Remittances Migrant Workers and FDI. JEJAK: Jurnal Ekonomi dan Kebijakan, 13(2), 280-291.

doi:https://doi.org/10.15294/jejak.v13i2.23543

Corresponding author : Khairah Ukhtiyani

Address: Universitas Negeri Yogyakarta

p-ISSN 1979-715X

E-mail: khairah.2018@student.uny.ac.id

e-ISSN 2460-5123 


\section{INTRODUCTION}

Indonesia is not only endowed in rich natural resources, but also the rich human resources, as Indonesia is the fourth largest population in the world. It causes the citizens to be very competitive in obtaining employment, and some of them will end up choosing to work abroad. The large number of Indonesians who choose to work abroad will certainly impact the state income and economic growth. From the economic growth, the level of achievement of a country's economic development can be measured (Fathoni, 2017). Each country has a different economic growth rate. The pace of Indonesia's economic growth from 1998 to 2018 are as follows:

Table 1. Indonesia's economic growth from

\begin{tabular}{cc}
\multicolumn{2}{c}{$1998-2018$ (percentages). } \\
\hline Year & $\begin{array}{c}\text { Indonesia's Economic } \\
\text { Growth }\end{array}$ \\
\hline 1998 & $-13,13$ \\
1999 & $-1,29$ \\
2000 & 6,48 \\
2001 & 3,88 \\
2002 & 4,38 \\
2003 & 4,78 \\
2004 & 5,03 \\
2005 & 5,69 \\
2006 & 5,51 \\
2007 & 6,28 \\
2008 & 6,1 \\
2009 & 4,5 \\
2010 & 6,1 \\
2011 & 6,5 \\
2012 & 6,23 \\
2013 & 5,78 \\
2014 & 5,02 \\
2015 & 4,79 \\
2016 & 5,02 \\
2017 & 5,07 \\
2018 & 5,17 \\
\hline
\end{tabular}

Source: Statistics Indonesia, 2020
In 1998-1999 economic growth in Indonesia had declined so much that there had been an economic increase. In 2000 Indonesia's economic growth recovered. Then the ups and downs of economic growth received from 20012016, the instability of economic growth caused by various factors, these factors will be identified in full. One of the factors that will discuss the remittance of Indonesian workers.

Indonesia is a country whose the economic growth is conducted through service export transactions. Migration provides diverse economic impacts on migrant households, countries of origin, and destination countries of migrants. Migration and remittances have direct and indirect effects on the welfare of the population in the country of origin of migrants. Remittances generated by migrants have the potential to increase state income and can reduce poverty. In addition, remittances can also enhance financial sector development, so as to stimulate economic growth. Indonesian migrant workers have a positive influence on the amount of remittances sent to their home country (Ardana, 2010; Suryantara, 2007). Remittance is the process on transferring money by the migrant workers to the family in their home country (Koser, 2007). The money sent by migrant workers is one of the largest cash flows in developing countries. On developing countries such as Indonesia, the remittances of migrant workers are quite large, especially when Indonesia is the origin of large scale migration. Worker remittances are an important part of international capital flows, especially in labor-exporting countries. In 1988, workers' remittances amounted to $\$ 65$ billion, accounting for nearly eight percents of service trade worldwide (Russell \& Teitelbaum, 1995).

In recent years, foreign workers from Asian have sent remittances of around \$ 8 billion per year to their home country. Based on the results of Cooray (2012) research, it was found that remittances have a positive effect on economic growth in South Asian. One of the 
benefits of remittance is it can improve the economic growth (Ratna, 2013). Hence, it can be concluded that the remittance of Indonesian Migrant Workers can increase economic growth. In addition, in order to improve the economic growth, money remittances are also an important source of valuable foreign exchange for laborexporting countries (Stahl \& Arnold, 1986).

Table 2. Information of remittances, received (\% of GDP) in 1998-2018

\begin{tabular}{cc}
\hline Year & $\begin{array}{c}\text { Remittances, received } \\
(\% \text { of GDP })\end{array}$ \\
\hline 1998 & 1.00 \\
1999 & 0.79 \\
2000 & 0.72 \\
2001 & 0.65 \\
2002 & 0.64 \\
2003 & 0.63 \\
2004 & 0.73 \\
2005 & 1.90 \\
2006 & 1.57 \\
2007 & 1.43 \\
2008 & 1.33 \\
2009 & 1.26 \\
2010 & 0.92 \\
2011 & 0.77 \\
2012 & 0.79 \\
2013 & 0.83 \\
2014 & 0.96 \\
2015 & 1.12 \\
2016 & 0.96 \\
2017 & 0.88 \\
2018 & 1.08 \\
\hline
\end{tabular}

Source: World bank, 2020.

Remittances in the percentage of remittance units per $\mathrm{PDB}$ have a positive trend but tend to be volatile. The increase in remittances in units of percentage of remittances occurred in 1998 and 2005. The increase in remittances in units of percentage of remittances in 1998 was caused by the number of Indonesian workers which increased significantly in line with the economic crisis in Indonesia. In 2005, the increase in remittances in terms of percentage of remittances per PDB was caused by the enactment of Law No. 39 of 2004 concerning the placement and protection of Indonesian workers abroad. Since the enactment of the Act, the receipt of remittances in nominal terms has increased significantly. In the following years, remittances in terms of percentage of remittances, received \% of GDP experienced along with the improvement of the Indonesian economy as indicated by the increasing GDP produced by Indonesia.

Besides remittance factors for migrant workers, FDI (Foreign Design Investment) in Indonesia also be examined. Each country needs capital to finance its development projects. If it turns out that the supply of savings in the country is not sufficient, then one way to get an injection of capital is to attract foreign direct investment (FDI). Foreign direct investment is an investment made by a foreign private sector to a certain country, usually in the form of multinational branch companies, multinational subsidiaries, licenses, joint ventures, or others. Economic growth supported by investment is considered to be able to increase productivity which also increase the growth). One of the main factors in the economic growth is capital accumulation, such as all forms of investment in the form of physical equipment, land, capital, and human resources (Setyari, Rustariyuni \& Aswitari, 2016). With the existence of Foreign Direct Investment (FDI), it supports the employment opportunities, increase state revenue from tax sources, and the existence of technology transfer. In addition, Foreign Direct Investment (FDI) tends to be more profitable and does not burden the country's economy compared to the flow of loans, financing development, and export credit, all of which are considered the state debt (Anwar et al, 2016). 
The theory of economic growth: Harrod-Domar's economic growth model explains that investment in the process of economic growth has a very decisive role, especially the dual character of investment (Jhingan, 1994) such as: a. Creating the revenue which is often referred as demand request. b. Enlarging the economic production capacity by increasing the capital stock as the impact of investment offers. While the net investment is still conducted, real income and output will grow continually. Therefore, FDI has a positive role in improving the economic growth. But after the 1998 economic crisis, FDI in terms of the percentage of FDI per GDP tends to decrease. This shows that the investment and business climate in Indonesia is not conducive.

Table 3. Percentage of FDI, net inflows (\% of GDP) Indonesia in 1998-2018

\begin{tabular}{cc}
\hline Year & $\begin{array}{c}\text { FDI net inflows } \\
\text { (\% of GDP })\end{array}$ \\
\hline 1998 & -0.25 \\
1999 & -1.33 \\
2000 & -2.75 \\
2001 & -1.85 \\
2002 & 0.07 \\
2003 & -0.25 \\
2004 & 0.73 \\
2005 & 2.91 \\
2006 & 1.34 \\
2007 & 1.60 \\
2008 & 1.82 \\
2009 & 0.90 \\
2010 & 2.02 \\
2011 & 2.30 \\
2012 & 2.31 \\
2013 & 2.55 \\
2014 & 2.82 \\
2015 & 2.29 \\
2016 & 0.48 \\
2017 & 2.02 \\
2018 & 1.89 \\
\hline
\end{tabular}

Source: World Bank, 2020.
The debate about the direct investment that has been going on for a long time. On the one hand, the direct investment gives a positive effect on economic growth, goals, Effendi \& Soemantri (2003). This positive impact occurs because of the transfer of technology and managerial expertise, the introduction of new production technologies, and access to international networks. For developing countries, the entry of foreign direct investment also means that it is available for soft loans. Meanwhile, the negative argument states that representatives of direct investment can refute Germinalis (1977). Different study results were also found by previous researchers. Aitken \& Harisson (1999) find that direct investment in Venezuela to the economy is very small (Effendi \& Soemantri, 2003). This finding was made with the results of studies conducted by Germidis (1977), Hadad \& Harison (1993) which state that direct investment does not have a significant effect on increasing economic growth.

The results of this empirical study differ from the findings obtained by Borensztein, Gregorio, \& Lee (1998) and Effendi \& Soemantri (2003), which defines the investment obtained directly to increase economic growth. This finding is supported by Alfaro, Chandra, KalemliOzcan, \& Sayek (200o) who also stated that direct investment has a positive impact on economic growth, especially in the financial sector. The different findings of several different researchers are interesting researchers to conduct research on direct investment in Indonesia, whether supporting the hypothesis that direct investment will increase economic growth or conversion.

While the remittance of Indonesian workers has a lot of research that has been owned, the evolution of acceptance of remittance receipts on economic growth in several developing countries. Abida \& Sghaier (2014) found remittances and economic growth to have a significant positive relationship, in a study of four countries (Tunisia, Morocco, 
Algeria, and Egypt) in North Africa using the Generalized Method of Moment (GMM) system of panel data analysis. Dhungel (2014) analyzed the effect of remittances on Gross Domestic Product (GDP) in Nepal, showing that the effect of remittances on GDP. This shows that the average remittance is spent in the unproductive sector. Tahir et al. (2015) analyzed the effect of receiving remittances on economic growth, using the variable remittance receipts, Foreign Direct Investments (FDI), total imports, and economic growth in Pakistan. Researchers found that receiving remittances and FDI had a positive and significant effect on economic growth, while interests had a negative effect on economic growth. Siddique et al. (2010) growth trends in remittance receipts to economic growth in Bangladesh, India, and Sri Lanka. Studies show that remittances do not have an influence on economic growth in Bangladesh and India. However, the effect of growth on economic growth in Sri Lanka. Other studies such as Chami et al. (2009) found that remittances have a negative effect on economic growth. Receiving remittances does help households get out of poverty. However, receiving remittances is not used for productive payments or is not used as capital to become an entrepreneur. Belmimoun et al. (2014) also found that remittances had a negative effect on economic growth in Algeria. This research shows that remittance has a direct influence on important goods or purchase of agricultural land, rising agricultural prices Further confirmed the receipt of remittance reports, the results of research from several previous studies, and research results that are different from case studies in different countries. Therefore, this is interesting to analyze, so that writers and readers can find out about the acceptance of remittances on economic growth in Indonesia.

Related to these problems, there are several things that will be analyzed in this study, namely: (1) The effect of sending Indonesian workers money on Indonesia's economic growth; (2) The effect of foreign direct investment (FDI) on economic growth in Indonesia; (3) The effect of remittances from Indonesian migrant workers and foreign direct investment (FDI) on Indonesia's economic growth.

\section{METHOD}

This study implemented quantitative analysis as the method. This analysis was used to analyze quantitative information in form of data that can be measured, tested, and displayed in the form of equations and tables. In calculating the research data, researchers used SPSS 21 application. The independent variable in this study was the remittance of Indonesian migrant workers remittance and FDI which were tested for their impacts on the dependent variable of economic growth. The research model implemented to see the relationship between the independent variables and the dependent variable were partially and simultaneously.

The data used as a sample in this study are data on the percentage of the number of remittances per GDP, FDI per GDP and Indonesia's economic growth in 1998-2018. The data collection method used in this study were documentation, or data collection the method is carried out by collecting all secondary data contained in the World Bank and the Central Statistics Agency (BPS). Data analysis starts by testing the violation/classical tests such as multicollinearity test, heteroscedasticity test, and autocorrelation test. 
Multicollinearity is necessary to consider whether a regression model is found to be related between independent variables. A good regression model does not occur between independent variables, because if it does, the variables are similar. To argue that multicollinearity problems occur can see the value of tolerance and its opponent Variance Inflation Factor (VIF). Sujianto (2007) said that if the value of the variance inflation factor (VIF) is not more than 10 then the model is free from multicollinearity. While the Heteroscedasticity Test takes decisions in the regression model, there is an unequal variance from the residue of one observation to another. To refute the presence or absence of heteroscedasticity in a model can be seen from the scatter plot pattern, Sujianto (2007) is not included as not heteroscedasticity if: 1 ) Dissemination of patternless data points 2) Data points are sought and sought 0 , and 3 ) Data the points cannot be collected only above or below them. And autocorrelation is defined as the relationship (revision) between observing members sorted according to time series or cross-sections of Gujarati (2003).

If the data is declared free from multicollinearity, heteroscedasity, autocorrelation then hypothesis testing could be conducted by using a regression test.

\section{RESULTS AND DISCUSSION}

The tests consisted of multicollinearity test, heteroscedasticity test, and autocorrelation test, in order to find out whether the model used was relevant or not.

In order to identify the possibility of multicollinearity, it could be done by using an additional regression (auxiliary regression), such as by regressing the independent variable with other independent variables. In order to see multicollinearity, the collinearity statistics were also used on:

Table 4. Collinearity Statistics

\begin{tabular}{cc}
\hline Tolerance & VIF \\
\hline .784 & 1.276 \\
.784 & 1.276 \\
\hline
\end{tabular}

Source: Author's compilation, 2020

From the calculation, the tolerance value was $0.784>$ from 0.100 . Meanwhile, the results from the calculation of the variance inflation factor was (VIF) $1.276<$ from 10.0o. Hence, it can be concluded that there is no multicollinearity between independent variables in the regression model.

Heteroscedasticity is the different variant that can make bias for the calculation, and the consequences of ordinary least square formula which will overestimate the true variance.The results of the heteroscedasticity test is are as follows:

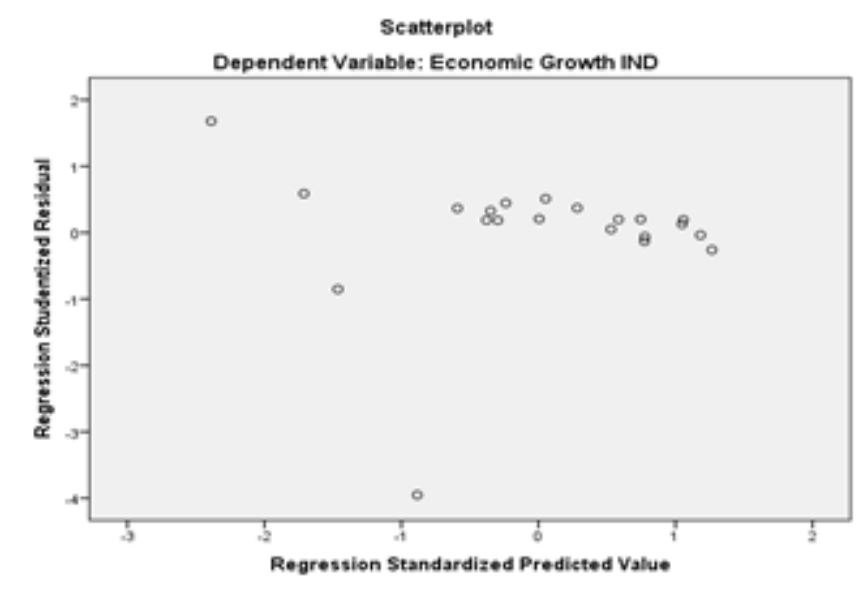

Figure 2. Scatterplot

In Figure, it revealed that the residual plot did not describe the existence of certain systematic patterns (linear or quadratic or wavy relationships, widening then narrowing), but it was more random (tends to spread). Hence, the regression equation used in this study was fulfilled the assumption of homoscedasticity or there was no heteroscedasticity symptom.

Autocorrelation can be defined as the correlation between various parts of observations ordered by time such as, in data of the time or cross sectional data. This test aimed 
to identify whether there was any correlation in regression linear model between the error of the intruder in the period $t$ with the error of the intruder on the variable $t-1$ (previous data). The results of the autocorrelation test were as follows:

Table 5. Runs test

\begin{tabular}{lr}
\hline & Unstandarized Residual \\
\hline Test Value & .75223 \\
Cases $<$ Test & 10 \\
Cases $>=$ Test & 11 \\
Total Cases & 21 \\
Number of Runs & 9 \\
Z & -.887 \\
Asymp. Sig. (2-tailed) & .375 \\
\hline
\end{tabular}

Source: Author's compilation, 2020
Asymp Value Sig (2-tailed) of $0.375>0.05$ then there are no symptoms of autocorrelation so the analysis can proceed.

The previous tests proved that there were no multicollinearity, heteroscedastasity, and autocorrelation, so the hypothesis testing could be conducted by using multiple regression. The results of multiple regression tests by using SPSS 21 program were as follows:

Table 6. Hypothesis testing on partial influence

\begin{tabular}{|c|c|c|c|c|c|c|}
\hline \multicolumn{7}{|c|}{ Coefficients $^{\mathrm{a}}$} \\
\hline & & \multicolumn{2}{|c|}{$\begin{array}{l}\text { Unstandardized } \\
\text { Coefficients }\end{array}$} & \multicolumn{2}{|c|}{$\begin{array}{c}\text { Standardized } \\
\text { Coefficients }\end{array}$} & \\
\hline \multicolumn{2}{|l|}{ Model } & B & Error & Beta & $\mathrm{t}$ & Sig \\
\hline \multirow[t]{3}{*}{1} & (Constant) & 4.249 & 3.440 & & 1.235 & .236 \\
\hline & REM & -1.202 & $3 \cdot 541$ & -.094 & -.339 & .739 \\
\hline & FDI & 1.034 & .761 & .376 & 1.359 & .194 \\
\hline
\end{tabular}

Dependent Variable: Economic Growth IND

Source: Author's compilation, 2020

In testing for the first hypothesis, the value of sig. For the effect of remittance of Indonesian workers on Indonesia's economic growth is $0.739>0.05$, it can be concluded that is no significant effect between remittances of Indonesian workers on Indonesia's economic growth in 1998-2018. The results of this study support the research of Chami et al. (2005) that remittances will cause moral hazard problems. Recipient households use remittances as a substitute for labor income (labor income), thereby reducing the desire to work and negatively impacting economic activity in various countries. The effect of remittances on economic growth in Indonesia much smaller than the findings of Meyer \& Shera (2017) in six developing countries in Europe and Albania. This is consistent with the opinion of Docquier (2017) which states that the impact of remittances on economic growth in high-income countries is far greater than in low-income countries.

Acceptance of remittances that continues to increase can provide positive growth to economic growth, but in this study which shows that remittance of Indonesian workers has no significant effect on economic growth in 19982018. This is seen from how the receipt of remittances spent by households, this greatly affects the size of economic growth. According to Adams \& Cuecuecha (2010) in Indonesia, 
more households receive remittances for spending on consumer goods and food. Households that receive international money transfers in Indonesia are households that are classified as poor or who are below the poverty line. Therefore, remittances received by households are mostly used for shopping for goods and food, for shopping for investment goods or housing.

Meanwhile, for testing the second hypothesis, the sig value for the effect of FDI on Indonesia's economic growth is 0,194 > 0.05 , it can be concluded that is rejected or there is no significant influence between FDI on Indonesia's economic growth in 1998-2018. The calculation results show the partial variable FDI has a negative influence on Indonesia's economic growth. These results illustrate that Indonesian investment is still very volatile. Indonesia has not become a priority because it has to invest capital from foreign investors. Evidenced by the World Investment Report report that Indonesia is still ranked 47th in foreign investment. Then, one of the foreign investors, one of which is a complicated and inefficient bureaucracy so that foreign investors are less interested in investing their capital in Indonesia. Like the length of investment licensing so that licensing is still expensive compared to competing countries.

Efforts to increase investor interest in investing in Indonesia are urgently needed. With regard to policies that must be issued to the Indonesian government, to make development policies related to policies to make investments for economic development in Indonesia in the future and also need to improve infrastructure to attract foreign investors. Related to investmentease, which is related to local communities, both related to fieldwork, transfer of knowledge, and technology that can support all parties.

Table 7. Hypothesis testing on simultaneous influence

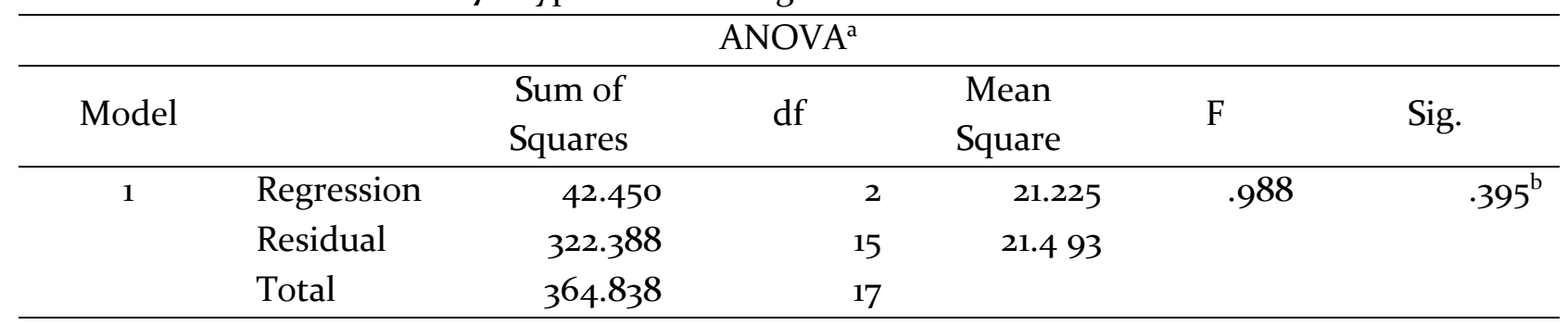

Dependent Variable: Economic Growth IND

Predictors: (Constant). FDI, REM

Source: Author's compilation, 2020

Using SPSS 21, a multiple regression test was carried out to see the effect of remittance of Indonesian workers and FDI as an independent variable on the dependent variable of Indonesia's economic growth simultaneously. Based on the output data in the ANOVA table, it was revealed that the effects of $\mathrm{X}_{1}$ and $\mathrm{X}_{2}$ simultaneously on $\mathrm{Y}$ were $0.395>0.05$. Therefore, the third alternative hypothesis is rejected. In other words, there is a simultaneous no effect of variable $\mathrm{X}$ on variable $\mathrm{Y}$. In conclusion, there is no effect of the remittance of Indonesian workers and FDI on Indonesia's economic growth in 1998-2018.

The results of this study partially or simultaneously state that FDI has a negative effect on economic growth, this is certainly contrary to the initial assumption of researchers. This result is also supported by previous studies namely research conducted by Octaviana, Cicy (2016) states FDI has no influence and is not significant to changes in economic growth, this is due to obstacles such as complicated licensing, and high licensing costs. Then these results are also strengthened 
by research conducted by Kholis, M (2012) stating that FDI has a negative impact on Indonesia's economic growth. According to Bhagwati (1994) shows that trade policy plays an important role in determining the effectiveness of FDI in distributing positive externalities in a country. In this case, he argues that export-oriented countries can capture the effect of "spillovers" on FDI more efficiently and, as such, will have higher growth rates. When viewed from the development of export-import, Indonesia is still import-oriented. The latest data in the 2018 word bank states that Imports of goods and services (\% of GDP) - Indonesia is 22,056 while Exports of goods and services (\% of GDP) are 20,966.

And the results of this study also state that labor remittances do not have an influence and are not significant in Indonesia's economic growth. Research on labor remittances in Saudi Arabia by Khalid. A (2013) this study looks at the development of remittance of Arab workers in 1970-2010, the results of statistical analysis show a significant relationship between the outflow of remittances and economic growth in the long run. While research into the role of remittances and financial development on economic growth conducted by Nyamongo, Esman M. et.al., (2012) in Africa during the 1980-2009 period found the results of research on remittance development as a complement to financial development, financial development in supporting weak economic growth. And subsequent research by Jawaid and Raza (2016) shows the negative effects of remittances on economic growth in Pakistan. Remittances are considered as an uninterrupted source of income, which can increase voluntary savings, which causes a decline in economic growth. The government must make a policy for this emergency agreement. Policymakers must create effective systems for installing inflows through formal financial channels for better control.

While the Study conducted by Katsushi S. Imai et.al., (2014) reviewed the remittance of GDP per capita growth using annual data panels for 24 Asian and Pacific countries. Results of Public Expenditures for Economic Growth However, our analysis also shows the volatility of capital flows such as remittances and FDI for economic growth. This means, while remittances contribute to a better economy, they are also a source of shock output.

\section{CONCLUSION}

The conclusion of this study is that in the period 1998-2018 the existence of remittances of Indonesian workers and FDI has not contributed significantly to economic growth in Indonesia. This correlation was found negative because the receipt of remittances by Indonesian workers was used by households for food consumption and expenditure, not for investment or to open a business.

Meanwhile, Indonesia's FDI bureaucracy is still inefficient and there is a need for infrastructure development in order to increase foreign investor interest. In addition, Indonesia is still oriented towards imports rather than exports.

\section{REFERENCES}

Abida, Z., \& Sghaier, I. M. (2014). Remittances, Financial Development and Economic Growth: The Case of North African Countries. Romanian Economic Journal, $17(51)$. 
Adams, R. H. J., \& Cuecuecha, A. (2010). The economic impact of international remittances on poverty and household consumption and investment in Indonesia. The World Bank.

Aitken, B. J., \& Harrison, A. E. (1999). Do domestic firms benefit from direct foreign investment? Evidence from Venezuela. American economic review, 89(3), 605-618.

Alfaro, L., Chandra, A., Kalemli-Ozcan, S., \& Sayek, S. (200o). FDI and economic growth: The role of local financial markets. Harvard Business School. Working Paper o1-o83

Alkhathlan, K. A. (2013). The nexus between remittance outflows and rowth: A study of Saudi Arabia. Economic Modeling, 33, 695-700.

Anwar, C. J. (2016). Factors Affecting Foreign Direct Investment (FDI) in the Southeast Asian Region. Media Trend, 11(2), 175-194.

Ardana, I. K., Sudibia, I. K., \& Wirathi, I. G. A. P. (2010). Factors Affecting the Remittance Delivery to the Region of Origin Case Study of Intern Workers from Jembrana Regency in Japan. PYRAMID.

Barajas, A., Gapen, M. T., Chami, R., Montiel, P., \& Fullenkamp, C. (2009). Do workers' remittances promote economic growth? (No. 2009-2153). International Monetary Fund.

Belmimoun, A., Kerbouche, M., Adouka, L., \& Mokeddem, R. (2014). The Impact Of Migrants' Remittances On Economic Growth Empirical Study: Case Of Algeria (1970-2010). European Scientific Journal, 10(13).

Borensztein, E., De Gregorio, J., \& Lee, J. W. (1998). How does foreign direct investment affect economic growth ?, The journal of international economics.

Chami, R., Fullenkamp, C., \& Jahjah, S. (2005). Are immigrant remittances flows a source of capital for development ?. IMF Staff papers, 52(1), 55-81.

Cooray, A. (2012). The impact of migrant remittances on economic growth: evidence from South Asia. Review of International Economics, 20(5), 985-998.

Dhungel, K. R. (2014). Does remittance in Nepal cause gross domestic product? An empirical evidence using vector error correction models. International Journal of Econometrics and Financial Management, 2(5), 168-174.

Docquier, Z. (2017). Remittances and Economic Growth: Analysis of the Direct and Indirect Effects.

Effendi, N., \& Soemantri, F. M. (2003, July). Foreign direct investment and regional economic growth in Indonesia: A panel study data. In The 6th Irsa International Conference, Regional Development in The Era of Decentralization: Growth, Poverty, and Environment, Bandung.

Fathoni, R. A. R., Al Musadieq, M., \& Supriono, S. (2017). The Influence of Intra-ASEAN Exports and Intra-ASEAN FDI on the Economic Growth of ASEAN Countries (Study on the Countries of Indonesia, Malaysia, Singapore, the Philippines, and Thailand 2006-2015). Journal of Business Administration, 45(1), 47-54.

Germidis, D. (1977). Transfer of technology by multinational corporations. Paris: development center of the organization for economic cooperation and development, general commission for sustainable development english sessions. Retrieved August 6, 2010.

Gujarati, D. N. (2003). Basic Econometrics "McGraw-Hill fourth edition. New York. 
Haddad, M., \& Harrison, A. (1993). Are there positive spillovers from direct foreign investment ?: Evidence from panel data for Morocco. Journal of development economics, 42(1), 51-74.

Jawaid, S. T., \& Raza, S. A. (2016). Effects of workers' remittances and its volatility on economic growth in South Asia. International Migration, 54(2), 50-68.

Jhingan, M. L. (1994). Money, Banking, International Trade \& Public Finance. Konark

Kholis, M. (2012). The impact of foreign direct investment on Indonesia's economic growth; Macroeconomic studies with the application of panel data. Journal of Organization and Management, 8(2), 111-120.

Koser, K., \& Wilkinson, P. (2007). International migration: A very short introduction. Oxford University Press.

Meyer, D., \& Shera, A. (2017). The impact of remittances on economic growth: An econometric model. EconomiA, 18(2), 147-155.

Nyamongo, E. M., Misati, R. N., Kipyegon, L., \& Ndirangu, L. (2012). Remittances, financial development and economic growth in Africa. Journal of economics and business, 64(3), 240-260.

Oktaviana, C. (2016). The Impact of Foreign Direct Investment (FDI) on Indonesia's Economic Growth 1980-2014 (Doctoral dissertation, UII).

Priambada, B. S. (2014). The Influence of the Moratorium on the Delivery of Indonesian Workers Abroad to the State Revenue and Expenditure Budget. Rechtstaat, 8 (1).

Ratha, D. (2013). The impact of remittances on economic growth and poverty reduction. Policy Brief, 8 (1), 1-13.
Raz, A. F., Indra, T. P., \& Artikasih, D. K. (2012). The global financial crisis and economic growth: Analysis of the East Asian economy. Bulletin of Monetary Economics and Banking, 15(2), 37-56.

Russell, S. S., \& Teitelbaum, M. S. (1995). International migration and international trade. The World Bank

Setyari, N. P. W., Rustariyuni, S. D., \& Aswitari, L. P. (2016). Capital Intensity, Openness, and the Economic Growth of the ASEAN 5. Journal of Indonesian Economy and Business, 31(3), 260-278.

Siddique, A., Selvanathan, E. A., \& Selvanathan, S. (2010). Remittances and Economic Growth: Empirical Evidence from Bangladesh India and Sri Lanka.

Stahl, C. W., \& Arnold, F. (1986). Overseas workers' remittances in Asian development. International Migration Review, 20(4), 899-925.

Statistics Indonesia. Indonesia's Economic Growth. Accessed on May 10, 2020, from https://www.bps.go.id/

Sujianto, A. E. (2007). Application of Statistics with SPSS for beginners. Jakarta: Literature Achievement.

Suryanata, I.G., \& Arya, Y. (2010). Analysis of Factors that Influence the Amount of Remittance Delivery by Non Permanent Migrants to the Area of Origin (case study in padang sambian kaja village). Undergraduate thesis, University of Udayana.

Tahir, M., Khan, I., \& Shah, A. M. (2015). Foreign remittances, foreign direct investment, foreign imports and economic growth in Pakistan: a time series analysis. Arab Economic and Business Journal, 10(2), 8289. 
World Bank Data. Remittances, received Indonesia. Accessed on May 10, 2020.

from https://data.worldbank.org/

World Bank Data. FDI net Indonesia Inflows.

Accessed on May 10, 2020.From https://data.worldbank.org/ 